\title{
Optimization and Characterization of Tyrosinases from Multi-enzyme Producing Fusarium solani and Fumago sp.
}

\author{
Olubusola Ayoola Odeniyi', Adebosola Ogunsanya' ${ }^{1}$, John Onolame Unuofin ${ }^{1,2^{\star}}$ \\ 1 Industrial Microbiology and Biotechnology Unit, Department of Microbiology, University of Ibadan, \\ Private Bag 5116, Ibadan 200284, Oyo State, Nigeria \\ 2 Department of Environmental, Water and Earth Sciences, Tshwane University of Technology, \\ Private Bag X680, Pretoria 0001, South Africa \\ * Corresponding author, e-mail: junuofin@gmail.com
}

Received: 10 January 2019, Accepted: 29 April 2019, Published online: 30 May 2019

\begin{abstract}
Tyrosinase is a copper-containing metalloprotein that catalyzes the oxidation of tyrosine, in particular, L-DOPA to L-Dopaquinone, which are precursors of brown pigments in some wounded eukaryotic tissues. The present study focused on screening, production and characterization of tyrosinase from multi-enzyme producing Fusarium solani B1 and Fumago sp. A total of 25 strains were isolated from rotting wood samples and screened for hydrolytic and oxidative multi-enzyme potentials using different polymeric substrates. The two most consistent strains: Fusarium solani B1 and Fumago sp. B13 were further evaluated for tyrosinase production. Some media cultural parameters and physiological conditions were optimized in order to maximize tyrosinase production. Incubation of Fumago sp. B13 and Fusarium solani B1 for 96 and $144 \mathrm{~h}$ in medium containing $2 \%$ and $0.2 \%$ ratios of Glucose and $\mathrm{NaNO}_{3}$ with $\mathrm{pH} 6$ and 7, respectively, was most suitable for tyrosinase production. Characterization of the partially purified tyrosinase from Fumago sp. B13 and Fusarium solani B1 exhibited optimal activities at $\mathrm{pH} 6-7,30^{\circ} \mathrm{C}$, and $1 \mathrm{mM} \mathrm{Cu}{ }^{2+}$, respectively, thereby suggesting their potentials for novel biotechnological applications.
\end{abstract}

Keywords

Fusarium solani B1, Fumago sp B13, multi-enzyme, tyrosinase, characterization

\section{Introduction}

With the advent of biotechnology, there has been a growing interest and demand for enzymes with novel properties. Considerable efforts are being directed towards the selection of microorganisms producing enzymes with enhanced catalytic properties and tolerance to extreme conditions charactersitic of industrial processes, such as temperature, salts, $\mathrm{pH}$ and many others. The potentials of using fungi as biotechnological sources of industrially relevant enzymes have stimulated interest in the exploration of their extracellular enzyme activity. Multienzymes could be produced through their induction on exposure to certain cultural conditions [1], through engineered microbes with multi-functions [2], through mixed culture of microbes [3], or ultimately, through directed evolution of enzymes [4]. High yielding strains, optimal fermentation conditions and efficient separation technologies have been anticipated to reduce the cost of producing many enzymes. Notwithstanding, pure enzyme extracts might still contain trivial amounts of a variety of accessory enzymes, which may be responsible for their multicatalytic potentials.

Tyrosinase is a copper containing enzyme present in both plant and animal tissues that catalyzes the production of melanin and other pigments from tyrosine by oxidation. A typical illustration is the blackening of a peeled or sliced tuber crop, during exposure to air [5]. From a mechanistic perspective, tyrosinases oxidize their substrates through hydroxylation of monophenol to $o$-diphenol (monophenolase or cresolase activity) and the oxidation of diphenol to $o$-quinones (diphenolase or catecholase activity), both using molecular oxygen, followed by a series of non-enzymatic steps, which may result in the formation of melanin [6]. These reactions may be responsible for the undesired enzymatic browning of fruits and vegetables, due to tissue injuries that may occur during senescence, harvest or postharvest handling. However, besides undesired 
browning, tyrosinases have been extolled for their role in the much desired organoleptic features of raisins, cocoa and fermented tea leaves among many others. In fungi, this phenomenon is associated with the differentiation of reproductive organs and spore formation, virulence of pathogenic fungi, and tissue protection after injury [7]. They achieve these tasks through the synthesis of melanin as a mechanism of defense against ultraviolet radiation, free radicals, gamma rays and extreme environmental conditions, as well as its contribution to the cell wall against hydrolytic enzymes, providing cell lysis.

Although tyrosinases have been scarcely considered, compared to its oxidative confrère, in the treatment of wastewater micropollutants, its biotechnological relevance in pharmaceuticals, nutraceuticals, and cosmeceuticals is renowned $[8,9]$. Interestingly, tyrosinases are being consisdered as a constituent of a functional amalgam-biosensor for the detection of inconsequential levels of volatile phenolics [10], thus highlighting its accuracy and sensitivity. Mushroom tyrosinases have attracted much biochemical interest due to the potentials already stated, and it has encouraged the exploratory search for novel fungal sources. A novel tyrosinase producing actinomycete strain has been isolated from Sahara soil [11]. Similarly, a study has been earlier conducted on two basidiomycetes, Agaricus bisporus and Pleurotus ostreatus, which had their tyrosinases purified and characterized [9]. However, to our knowledge, this is the first account of tyrosinase production from Fumago sp. and its characterization.

\section{Materials and methods}

\subsection{Collection and isolation of microorganisms}

Seven chunks of rotting wood samples and eight mushroom samples, growing on rotting logs of wood were collected and rinsed in $1 \%$ hypochlorite solution (to reduce microbial contamination) for $10 \mathrm{~min}$ then thoroughly rinsed with sterile water. These samples $\left(5 \mathrm{~mm}^{2}\right)$ were centrally located on Petri dishes containing sterilized and cooled potato dextrose agar (LAB-M) to which $100 \mu \mathrm{g} \mathrm{mL} \mathrm{m}^{-1}$ of streptomycin was added to inhibit bacterial growth. Plates were incubated at room temperature for $120 \mathrm{~h}$. The growths which occurred on the plates as fungal mycelia were subcultured by aseptically transferring $8 \mathrm{~mm}$ mycelia plugs successively onto fresh PDA plates with the aid of a sterile cork borer, until pure cultures were observed and these were maintained on potato dextrose agar slants at $4{ }^{\circ} \mathrm{C}$.

\subsection{Biocatalytic activity of fungal strains}

The fungi isolated were qualitatively screened for catalytic enzymes such as amylases, cellulases, tannases, pectinases, proteases, mannanses and tyrosinases. Agar plugs $(8 \mathrm{~mm})$ from 7 day old fungal cultures were aseptically and centrally inoculated on Petri plates containing about $15 \mathrm{~mL}$ of different screening media, and were analyzed as described below. Amylase was determined on soluble starch agar medium comprising (g/L) starch: 20; yeast extract: 0.5; $\mathrm{KH}_{2} \mathrm{PO}_{4}: 10 ;\left(\mathrm{NH}_{4}\right)_{2} \mathrm{SO}_{4}: 10.5 ; \mathrm{MgSO}_{4} .7 \mathrm{H}_{2} \mathrm{O}: 0.3 ; \mathrm{CaCl}_{2}$ : 0.5 ; to which $1 \mathrm{~mL}$ of a cocktail of elements $(\mathrm{g} / \mathrm{L})$ : $\mathrm{FeSO}_{4} \cdot 7 \mathrm{H}_{2} \mathrm{O}: 0.004 ; \mathrm{MnSO}_{4} .7 \mathrm{H}_{2} \mathrm{O}: 0.004$ and $\mathrm{ZnSO}_{4} \cdot \mathrm{H}_{2} \mathrm{O}$ : 0.004 was added. The plates were incubated and observed for $72 \mathrm{~h}$ after which they were flooded with Gram's Iodine. A clear hydrolytic zone around the cultures on the starch plates against a blue/black background was taken as positive, while a negative experiment would not reveal any zone around the inoculated culture.

Cellulase was determined on a medium described by Islam and Roy [12] with slight modifications, which entailed the replacement of $2 \mathrm{~g}$ gelatin with $0.5 \mathrm{~g}$ yeast extract. Tannic acid agar medium (TAA) as described by Pinto et al. [13] was used for screening of tannase activity. Pectinase was determined on $1 \%$ citrus pectin supplemented Czapek mineral salt screening agar medium containing $(\mathrm{g} / \mathrm{L}): \mathrm{NaNO}_{3}$ : 2; $\mathrm{K}_{2} \mathrm{HPO}_{4}: 1.0 ; \mathrm{MgSO}_{4} .7 \mathrm{H}_{2} \mathrm{O}: 0.5 ; \mathrm{KCl}: 0.5$; Peptone: 2 ; Agar: 20; $\mathrm{pH}$ 6.5. Protease activity was screened for on a skim milk medium described by Polley and Ghosh [14]. Mannanase activity was assayed on a basal salt medium containing (g/L): $\mathrm{NaNO}_{3}: 2.0 ; \mathrm{K}_{2} \mathrm{HPO}_{4}: 1.0 ; \mathrm{MgSO}_{4} \cdot 7 \mathrm{H}_{2} \mathrm{O}$ : 0.5; KCl: 0.5; Peptone: 2.0; Agar: 20; pH 6.5 supplemented with $1 \%$ gum acacia. Tyrosinase was screened for on a medium described by Raval et al. [15]. The tyrosine screening medium contained (g/L): Peptone: 5; Yeast Extract: 3; L-tyrosine: 5; Agar: 20; $\mathrm{pH}$ 7. All the plates were incubated at $28{ }^{\circ} \mathrm{C}$ for $72 \mathrm{~h}$ and thereafter stained with iodine, except for protease plate, which exhibited a clear zone post-incubation, as well as tannase and tyrosinase screening plates, which were only observed for color changes. The appearance of brown halos around fungal growth was indicative of hydrolytic or oxidative activities of the respective enzymes.

\subsection{Fungal selection and identification}

The isolates were identified macroscopically and microscopically using the slide agar method [16] after staining with lactophenol cotton blue stain. Simplified key to some selected common genera [17] was used for identification of isolates to the genus level. 


\subsection{Production of tyrosinase}

Tyrosinase was produced following the method of Roy et al. [18]. Erlenmeyer flasks $(250 \mathrm{~mL})$ containing $100 \mathrm{~mL}$ of tyrosinase production broth (g/L): Starch; 25, Glucose; 10, Yeast extract; $2, \mathrm{CaCO}_{3} ; 3$, and $1 \mathrm{~mL}$ of a trace salt solution containing ( $1 \%$ of $\mathrm{FeSO}_{4}, \mathrm{CuSO}_{4}, \mathrm{ZnSO}_{4}, \mathrm{MnCl}_{2}$ ), were autoclaved at $121^{\circ} \mathrm{C}$ for $15 \mathrm{~min}$. After cooling, $10 \mathrm{~mL}$ $0.1 \%$ of tyrosine was added to the medium and each flask was inoculated with five agar plugs ( $5 \mathrm{~mm}$ diameter) from $72 \mathrm{~h}$ old fungal cultures and incubated at room temperature for seven days. After the days of incubation, the extracellular enzyme from each fungal isolate was obtained by centrifuging the biomass at $8000 \mathrm{rpm}, 4{ }^{\circ} \mathrm{C}$ for $15 \mathrm{~min}$ and the supernatant was assayed for tyrosinase activity.

\subsection{Determination of tyrosinase activity}

The continuous spectrophotometric rate determination method of Naraoka et al. [19] was employed, with modifications. Reaction cocktails containing $(0.9 \mathrm{~mL}$ of deionized water, $1 \mathrm{~mL}$ of $0.5 \mathrm{M}$ sodium phosphate buffer at pH 6.5 and $1 \mathrm{~mL}$ of $0.2 \mathrm{mM}$ tyrosine solution) were prepared and mixed at $25{ }^{\circ} \mathrm{C}$. The mixture was shaken with a vortexer for 3 to $5 \mathrm{~min}$ after which $0.1 \mathrm{~mL}$ of the enzyme sample was added to the cocktail. One international unit (IU) of enzyme activity was described as the amount that catalyzes the transformation of $1 \mu$ mole of substrate to product per min at $\mathrm{pH} 6.5$ at $25^{\circ} \mathrm{C}$ in a $3 \mathrm{~mL}$ reaction mix, and was calculated as follows, using the molar absorption coefficient of dopachrome $\left(3600 \mathrm{M}^{-1} \mathrm{~cm}^{-1}\right)$ :

$$
I U=\frac{\Delta A}{\Delta t} \times 10^{6} \mu \mathrm{m} \times V_{f}(L) / \varepsilon \times M
$$

where;

$\varepsilon=$ molar absorption coefficient

$V_{f}=$ final volume in the cuvetter $(l)$

$A=$ absorbance

$t=$ time (min).

\subsection{Optimization of fermentation conditions for tyrosinase production and time course study}

Fermentation experiments were conducted in $250 \mathrm{~mL}$ Erlenmeyer flasks containing $100 \mathrm{~mL}$ modified basal salt medium. Tyrosinase production was optimized by a traditional 'one factor at a time' (OFAT) approach, which entailed varying $\mathrm{pH}$ (3-9) using phosphate buffers ( $\mathrm{pH} 4-7$ ) and tris buffer ( $\mathrm{pH} 8$ and 9). Carbon sources (1\%) (maltose, lactose, fructose, sucrose) were varied, using glucose as control, as well as $0.2 \%$ nitrogenous sources (peptone, ammonium sulphate, urea and sodium nitrate) where yeast extract served as the control. Time course of tyrosinase production was determined by the extraction of aliquots of fermented culture broth at successive periods of incubation for analysis.

\subsection{Partial purification of tyrosinase from the crude extract}

A hundred millilitre $(100 \mathrm{~mL})$ supernatant from a fungal culture broth was obtained through centrifugation at $8000 \times \mathrm{g}$ for $15 \mathrm{~min}$ and concentrated with ammonium sulphate (40\% saturation). After overnight storage at $4{ }^{\circ} \mathrm{C}$, the ammonium sulphate precipitated protein was centrifuged at $10000 \mathrm{rpm}, 4{ }^{\circ} \mathrm{C}$ for $20 \mathrm{~min}$. The precipitate $(10 \mathrm{~mL})$ was resuspended in $90 \mathrm{~mL}$ of $0.2 \mathrm{M}$ phosphate buffer $(\mathrm{pH} 7.0)$ with continuous stirring under refrigeration and was then checked for enzymatic activity as well as total protein content. Thereafter, dissolved precipitates were transferred into a preconditioned dialysis bag and sealed at both ends. The dialysis bag with its content was suspended overnight at $4{ }^{\circ} \mathrm{C}$ in a glass beaker containing $0.2 \mathrm{M}$ phosphate buffer (pH 7.0) with stirring. The dialysate was checked for tyrosinase activity [18] and the total protein content measured following the Bradford method of 1976 [20].

\subsection{Tyrosinase characterization}

Temperature effects on tyrosinase activity was determined at different temperature ranging from $30{ }^{\circ} \mathrm{C}-70{ }^{\circ} \mathrm{C}$ by preincubating the purified extracellular enzyme at the stated temperature ranges for $15 \mathrm{~min}$ in a constant temperature water bath. After this, the residual tyrosinase activity was determined [21] as earlier described in Section 2.5.

The effect of $\mathrm{pH}$ modifications on tyrosinase activity was determined by preincubating equal volumes of the enzyme and phosphate buffer ( $\mathrm{pH}$ 5.0-7.0) and tris buffer (8.0 and 9.0 ) at $28{ }^{\circ} \mathrm{C}$ for $15 \mathrm{~min}$. The activity in the reaction mixtures was determined under the stated assay conditions. The effect of $1 \mathrm{mM}$ metal ions $\left(\mathrm{Hg}^{2+}, \mathrm{Ca}^{2+}, \mathrm{Mn}^{2+}, \mathrm{Mg}^{2+}\right.$ and $\mathrm{Cu}^{2+}$ ) from chloride salts of the metals on tyrosinase activity was determined. The enzyme was incubated with different metal salts (equal volumes) at room temperature for $10 \mathrm{~min}$. The activities were then determined under assay conditions as described above.

The kinetics parameters $\left(K_{M}\right.$ and $\left.V_{\max }\right)$ were determined for the purified tyrosinase, using increasing tyrosine concentration as assay substrate $(0.1$ to $0.5 \mathrm{mM})$ at $30{ }^{\circ} \mathrm{C}$ in $100 \mathrm{mM}$ phosphate buffer at $\mathrm{pH}$ 7.0. The $K_{M}$ and $V_{\max }$ values were determined from the Michaelis-Menten plots. 


\section{Results and discussion}

Fungi are capable of utilizing complex chemical substances as energy sources, due to their competitive saprophytic ability, which is expressed by fast mycelia growth, spores production, presence of efficient and extensive systems of powerful enzymes. In our study, a total of 25 fungi were isolated from rotting wood samples, where five (B1, B9, B13, B18, and B23) demonstrated consistent multi-enzyme characteristics by producing different zones of hydrolysis or oxidation on the screening substrates: starch, cellulose, tannic acid, pectin, casein, gum acacia, and tyrosine (Table 1). However, among these five isolates, the most consistent multi-enzyme activity was observed with isolates B1 and B13, other interesting observations were recorded in Table 1. The remarkable multi-enzyme capabilities of the fungal strains could, in part, be stimulated by the components of the medium, particularly the presence of a basic nutrient which serves as a source of energy, and also induce the meticulous choice of metabolic pathways for nutrient breakdown, and absorption by the fungi. A similar observation of multi-enzyme capabilities was reported by Liu et al. [1], where they employed switchgrass as a source of energy and thereafter were able to achieve its saccharification through the secretion of cellulase and a retinue of accessory enzymes. Isolates B1 and B13 were identified by physical morphology and microscopy as Fumago sp. B13 and Fusarium solani B1, according to the descriptions of Pictorial Atlas of Soil and Seed Fungi [17]. The aerial white cottony mycelia on PDA, and the corresponding distinct sickle shape of the ascus suggested isolate B1 belonged to the genus, Fusarium. On the other hand, dark grey velvety growth on PDA, and the subsequent appearance of irregular spores borne on short conidiophores and on ordinary hyphae rich in oil globules

Table 1 Screening of fungal strains possessing enzyme activities at $72 \mathrm{~h}$.

\begin{tabular}{|c|c|c|c|c|c|c|c|}
\hline Code & Amylase & Cellulase & $\begin{array}{r}\text { Pectinase } \\
(\mathrm{mn}\end{array}$ & $\begin{array}{l}\text { Tannase } \\
\text { of hydroly }\end{array}$ & $\begin{array}{l}\text { Mannanase } \\
\text { xidation) }\end{array}$ & Protease & Tyrosinase \\
\hline
\end{tabular}

\begin{tabular}{|c|c|c|c|c|c|c|c|}
\hline B1 & 23 & 15 & 19 & 29 & 16 & 20 & 18 \\
\hline B2 & 4 & 0 & 5 & 12 & 0 & 2 & 7 \\
\hline B3 & 0 & 13 & 8 & 0 & 7 & 5 & 0 \\
\hline B4 & 14 & 6 & 0 & 5 & 6 & 18 & 0 \\
\hline B5 & 12 & 8 & 12 & 13 & 0 & 10 & 7 \\
\hline B6 & 0 & 13 & 16 & 0 & 12 & 14 & 9 \\
\hline B7 & 10 & 0 & 15 & 11 & 18 & 0 & 5 \\
\hline B8 & 0 & 16 & 0 & 10 & 0 & 17 & 0 \\
\hline B9 & 17 & 13 & 15 & 16 & 11 & 9 & 10 \\
\hline B10 & 13 & 0 & 10.5 & 0 & 10 & 2 & 18 \\
\hline B11 & 15.5 & 20 & 0 & 6 & 14 & 5 & 0 \\
\hline B12 & 5 & 11 & 9 & 0 & 0 & 3 & 8 \\
\hline B13 & 18 & 25 & 17 & 28 & 17 & 15 & 20 \\
\hline B14 & 17 & 12 & 5 & 7.5 & 4.5 & 3 & 0 \\
\hline B15 & 5 & 6 & 0 & 8 & 18 & 7 & 2 \\
\hline B16 & 10 & 20 & 13.1 & 9 & 7 & 0 & 9 \\
\hline B17 & 15 & 7 & 8 & 9 & 0 & 0 & 8.5 \\
\hline B18 & 7 & 16 & 26 & 18 & 10 & 4 & 6 \\
\hline B19 & 24 & 6 & 7 & 4.5 & 6 & 7 & 5 \\
\hline B20 & 3 & 9 & 0 & 7 & 0 & 1 & 2 \\
\hline B21 & 7 & 2.5 & 0 & 12 & 8 & 3 & 1 \\
\hline B22 & 3 & 5 & 8 & 14 & 6 & 1 & 0 \\
\hline B23 & 3 & 15.5 & 17 & 16 & 12 & 4 & 6 \\
\hline B24 & 11 & 0 & 8 & 5 & 0 & 3 & 4 \\
\hline B25 & 4.5 & 5 & 0 & 7 & 7.5 & 8 & 0 \\
\hline
\end{tabular}


were characteristic of Fumago sp. B13. Our findings of the Fusarium, an ascomycete, were congruent with the outcome of the phylogenetic study of Halaouli et al. [22], that fungal tyrosinases are clustered in basidiomycetes, ascomycetes and deuteromycetes.

\subsection{Optimization studies on tyrosinase production}

Enzymatic oxidation of tyrosine was carried out with the tyrosinase produced by Fusarium solani B1 and Fumago sp. B13 using atmospheric molecular oxygen, which effected the production of a black pigment [21]. In our study, it was necessary that copious enzyme titers were produced, therefore, we investigated effect of selected cultural and nutritional parameters on tyrosinase outputs by the fungi.

Maximum tyrosinase production was observed at $\mathrm{pH}$ of 6 and 7 in the basal medium for Fumago sp. B13 and Fusarium solani B1 respectively (Fig. 1). Tyrosinase activity ranged from 120-580 U/mL for Fusarium solani B1 and $100-440$ U/mL in Fumago sp. B13 respectively. A growth medium of acidic to neutral increasingly favoured tyrosinase activity in Fusarium solani B1. The same trend was observed in Fumago sp. B13 but at pH beyond 6, activities reduced and the least activity was recorded at $\mathrm{pH} 9$ $(100 \mathrm{U} / \mathrm{mL})$. One amongst other possible reasons for this phenomenon might be the inhibitory effect of the higher concentration of $\mathrm{OH}^{-}$on fungal oxidases as $\mathrm{pH}$ advanced to towards neutrality, and eventually, the alkaline regime. However, Valipour and Arikan [23] reported a maximum yield of tyrosinase production between $\mathrm{pH} 6$ and 7, which corroborates our observations. However, this contrasts the studies of Krishnaveni et al. [24], who opined that the optimum $\mathrm{pH}$ for the growth of their fungus (5.0-5.5) was in concordance with its maximum tyrosinase production.

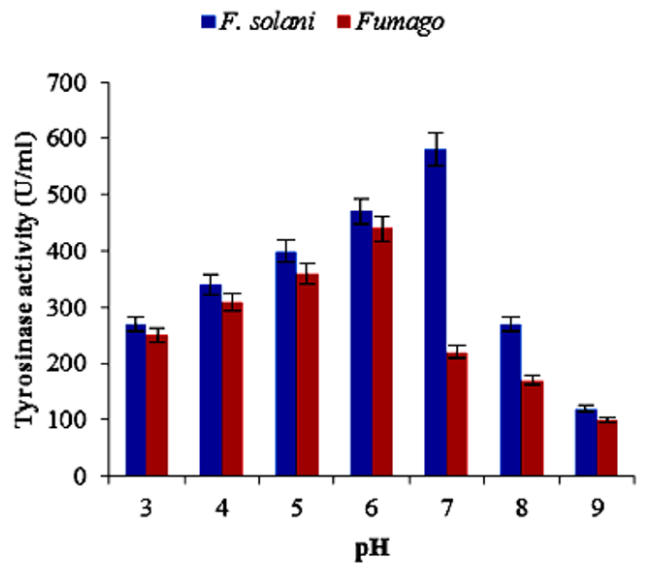

Fig. 1 Influence of $\mathrm{pH}$ on the production of tyrosinase by F. solani Bland Fumago sp. B13
Glucose, when employed as the carbon source, elicited maximum tyrosinase yield in both isolates (Fusarium solani B1; $500 \mathrm{U} / \mathrm{mL}$, Fumago sp. B13; $580 \mathrm{U} / \mathrm{mL}$ ). Lactose also yielded considerably high tyrosinase titers, while a sucrose-supplemented medium produced the least tyrosinase (Fig. 2).

Agarwal et al. [25] reported the constitutive and enhanced production of tyrosinase at $2 \%$ concentration of glucose. However, Moshtaghioun et al. [26] selected sucrose for the optimization of growth of a tyrosinase producing fungus, Neurospora crassa and based their prereference on the presence of invertase in its membrane. As reflected in Fig. 3, maximum tyrosinase production was observed when sodium nitrate was used as the nitrogen source with an activity of $660 \mathrm{U} / \mathrm{mL}$ and $490 \mathrm{U} / \mathrm{mL}$ for Fusarium solani B1 and Fumago sp. B13. However, the least activity was observed when urea and peptone were

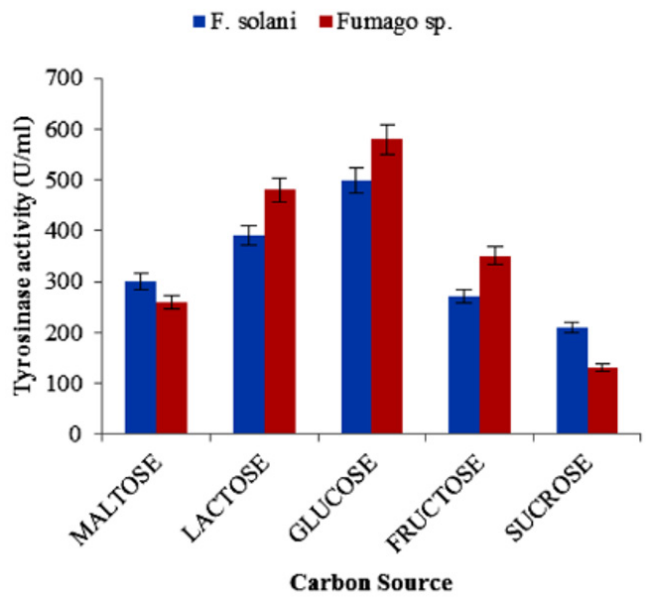

Fig. 2 Influence of different carbon sources on the production of tyrosinase by $F$. solani $\mathrm{B} 1$ and Fumago sp. B13

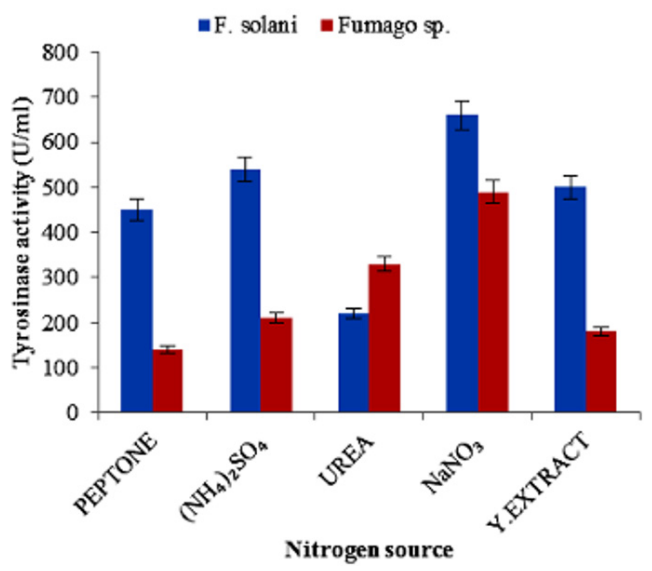

Fig. 3 Influence of different nitrogen sources on the production of tyrosinase by $F$. solani Bland Fumago sp. B13 
used as the nitrogen sources in the medium for Fusarium solani B1 (220 U/mL) and Fumago sp. B13 (140 U/mL). This could be due to the repressive effects of amino acids and analogues which might be present in the production of tyrosinase by some fungi [27]. Conversely, Majidi and Aksoz [28], reported that maximum enzyme production was obtained when sodium nitrate was used as nitrogen source, but they concluded that best nitrogen sources might differ from one fungus to another.

The fungal secretion of tyrosinase and its associated melanin synthesis were evaluated by the afore-mentioned exogenous sources. Fig. 4 portrayed the time course for maximum production of tyrosinase by Fusarium solani B1 and Fumago sp. B13). It was observed that tyrosinase production peaked on the $6^{\text {th }}$ day $(560 \mathrm{U} / \mathrm{mL})$ and $4^{\text {th }}$ day $(500 \mathrm{U} / \mathrm{mL})$ by Fusarium solani $\mathrm{B} 1$ and Fumago sp. B13, respectively. The factors affecting our findings may not be precisely identifiable at the moment, however, our deduction disagrees with the observations of Duarte et al. [29] and Valipour and Arikan [23], who reported $48 \mathrm{~h}$ and $16 \mathrm{~h}$ optima for Pycnoporus sanguineus and Bacillus megaterium, respectively.

\subsection{Enzyme purification and characterization}

The crude enzyme from Fusarium solani B1 and Fumago sp. B13 was partially purified using the ammonium sulphate fractionation (40\%) and dialysis. With each purification step, the residual tyrosinase activity of Fusarium solani and Fumago sp. reduced with the activity in dialysed samples being least $(140 \mathrm{U} / \mathrm{mL}$ and $160 \mathrm{U} / \mathrm{mL}$, respectively for Fusarium solani and Fumago sp.). However, the specific activity of the filtrates increased, hence portraying the inverse relationship between enzyme activity and the specific activity of the tyrosinases (Table 2).

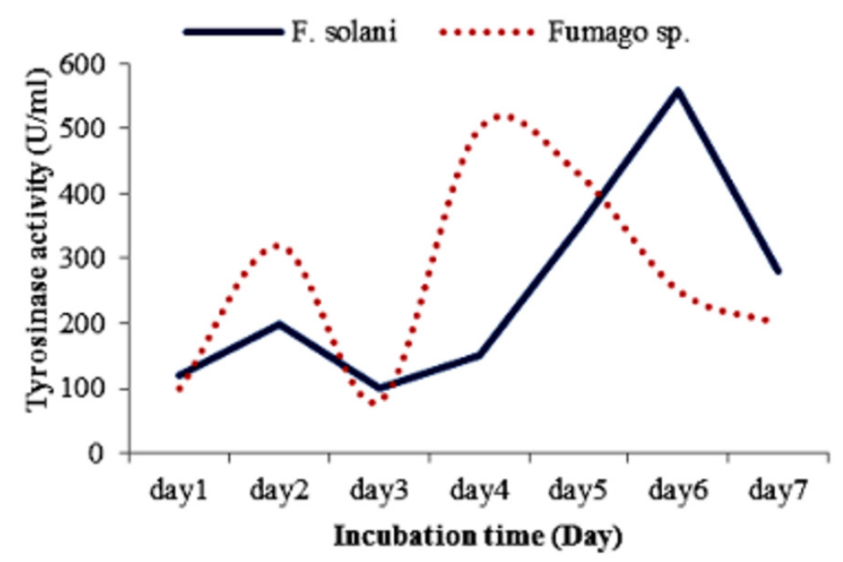

Fig. 4 Time course for the production of tyrosinase by Fusarium solani B1 and Fumago sp. B13
Fusarium solani $\mathrm{B} 1$ and Fumago sp. B13 tyrosinases were greatly enhanced by $1 \mathrm{mM} \mathrm{Cu}^{2+}$ and $\mathrm{Mg}^{2+}$ while other metals had little effect on the tyrosinase activties. The catalytic outputs of the tyrosinases were reduced by $\mathrm{Hg}^{2+}$ (Fig. 5). In a similar study, Harir et al. [11] reported the enhancing effects of preincubation of tyrosinase with $\mathrm{Cu}^{2+}$ and $\mathrm{Mg}^{2+}$ among other cations, which had little adverse effects overall.

Fig. 6 showed that Fusarium solani $\mathrm{B} 1$ and Fumago sp. $\mathrm{B} 13 \mathrm{had}$ the highest tyrosinase activity at $30^{\circ} \mathrm{C}$ and the lowest at $70{ }^{\circ} \mathrm{C}$. The increasing temperature was observed to result in a reduction of the enzyme activity, and this might be attributed to the influence the temperature of the environment wherein the fungi were isolated had on their physiology. Earlier studies have shown temperature maxima for fungal tyrosinases to range between $25^{\circ} \mathrm{C}$ and $35^{\circ} \mathrm{C}[23,30]$. Generally, it could be assumed that the susceptibility of the tyrosinases to inactivation at higher temperatures might be a result of their molecular structure, however, further studies should be conducted to ascertain this claim. Consequently, their efficiencies in applications requiring higher temperature regimes might be inconsequential. Thus, more strategic

Table 2 Purification of tyrosinase from Fusarium solani B1 and Fumago sp. B13

\begin{tabular}{lcccc}
\hline & & $\begin{array}{c}\text { Enzyme } \\
\text { activity } \\
(\mathbf{U} / \mathbf{m l})\end{array}$ & $\begin{array}{c}\text { Protein } \\
\text { content } \\
(\mathbf{m g} / \mathbf{m l})\end{array}$ & $\begin{array}{c}\text { Specific } \\
\text { activity (U/mg } \\
\text { protein/ml) }\end{array}$ \\
\hline $\begin{array}{l}\text { Fusarium } \\
\text { solani B1 }\end{array}$ & $\begin{array}{c}\text { Crude } \\
\left(\mathrm{NH}_{4}\right)_{2} \mathrm{SO}_{4} \\
\text { precipitation }\end{array}$ & 180 & 4.842598 & 37.17013 \\
& $\begin{array}{c}\text { Dialysis } \\
\text { Fumago }\end{array}$ & 140 & 3.455965 & 49.19031 \\
sp. B13 & $\begin{array}{c}\text { Crude } \\
\left(\mathrm{NH}_{4}\right)_{2} \mathrm{SO}_{4}\end{array}$ & 200 & 4.02436 & 49.69734 \\
& $\begin{array}{c}\text { precipitation } \\
\text { Dialysis }\end{array}$ & 190 & 3.106184 & 61.1683 \\
& & 2.512804 & 63.67389 \\
\hline
\end{tabular}

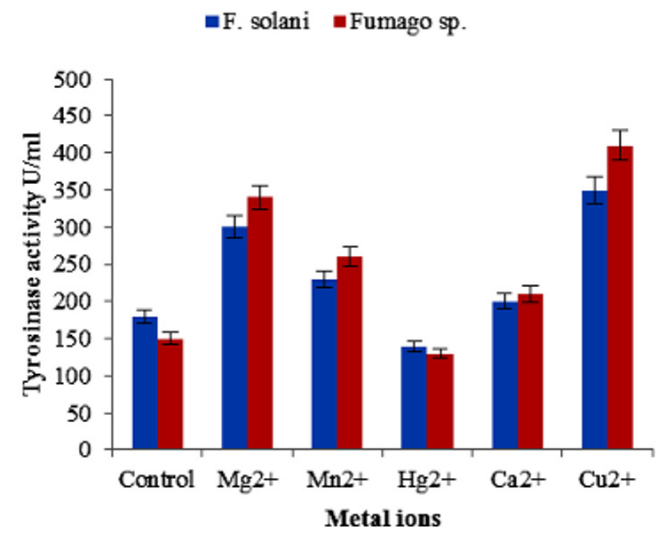

Fig. 5 Effect of metal ions $(1 \mathrm{mM})$ on the tyrosinase activities of Fusarium solani B1 and Fumago sp. B13. 


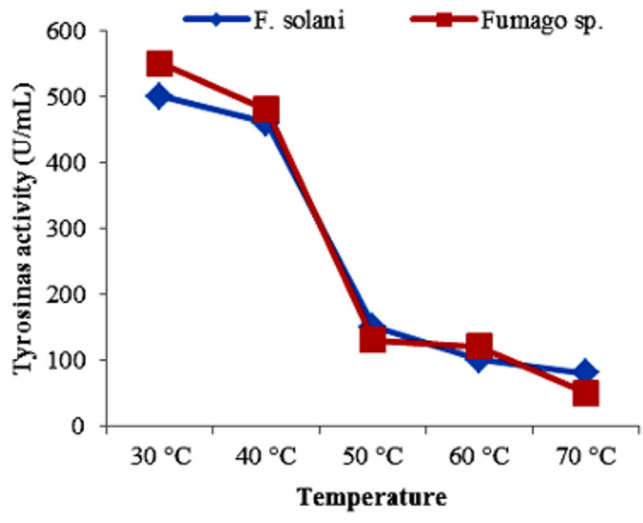

Fig. 6 Effect of temperature on the tyrosinase activities of Fusarium solani B1 and Fumago sp. B13.

screening techniques, extreme environments and structural modifications might also be considered when searching for tyrosinases with novel properties.

Fusarium solani $\mathrm{B} 1$ had the highest tyrosinase activity at a $\mathrm{pH}$ of 7 from which it gradually declined into an alkaline regime while Fumago sp. B13 had the highest tyrosinase activity at a $\mathrm{pH}$ of 6 after which it also gradually declined (Fig. 7). A possible reason for this has been earlier mentioned in the text, and our observations are in tandem with the reports of Axambayeva et al. [31] and Zou et al. [32]. Conversely, due to the harsh environments which are anticipated for real life applications, it would be highly necessary to address the bottleneck a narrow $\mathrm{pH}$ range would confer on catalytic activities.

It was observed that substrate concentrations (0.1-0.5 mM) was directly proportional to tyrosinase activity, where a maximum activity of $560 \mathrm{U} / \mathrm{mL}$ recorded by $F$. solani tyrosinase (Fig. 8). This is similar to the observation of Axambayeva et al. [31]. Therefore, the enzyme kinetics were extrapolated from Michaelis Menten plots using the non-linear regression method [33] where $V_{\max }$ was 0.4034 units and $K_{M}$ was $0.0109 \mathrm{mM}$ for Fusarium

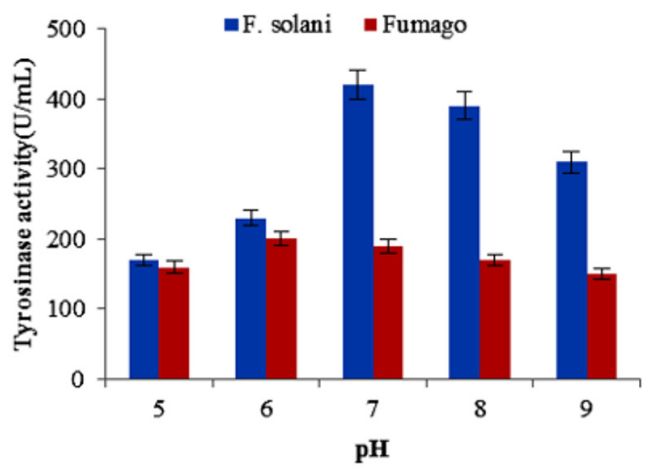

Fig. 7 Effect of $\mathrm{pH}$ on the tyrosinase activities of Fusarium solani B1 and Fumago sp. B13.

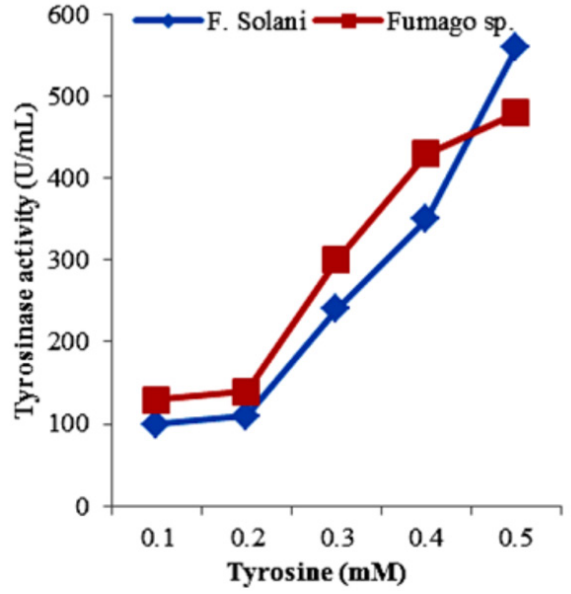

Fig. 8 Effect of increasing substrate concentration on the tyrosinase activities of Fusarium solani (B1) and Fumago sp. (B13).

solani B1 tyrosinase, and $0.4026\left(V_{\max }\right)$ and $0.0097 \mathrm{mM}$ $\left(K_{M}\right)$ for Fumago sp. B13 tyrosinase, respectively (Fig. 9). From the kinetics determined, it could be assumed that the fungal proteins displayed a high affinity for the substrate and could transform it at a rapid rate. Furthermore, the particular uniqueness of the tyrosinases reported in this study is their relatively higher substrate affinity, compared to other sources [11, 32, 34-36], which might imply their potential precision and efficient conversion of substrates, if applied at industrial scale. Therefore, further investigations should be encouraged to fully elucidate the potentials of these reported strains.

\section{Conclusion}

Fusarium solani $\mathrm{B} 1$ and Fumago sp. B13 were isolated from rotting wood samples. They were able to display remarkable zones of hydrolysis or oxidation on media supplemented with starch, cellulose, tannic acid, pectin, gum acacia, casein and tyrosine, thereby ascertaining their multi-enzyme activities and their potentials for multi-enzyme related biotechnological applications.

Tyrosinase production in these fungi was enhanced in a medium supplemented with $1 \%$ glucose, $0.2 \% \mathrm{NaNO}_{3}, \mathrm{pH}$ of 6-7. Characterization of tyrosinase from Fusarium solani B1 and Fumago sp. B13 showed that the highest activities occurred at a temperature of $30^{\circ} \mathrm{C}$, in the presence of $(1 \mathrm{mM})$ $\mathrm{Cu}^{2+}$, at a substrate concentration of $0.5 \%$ and $\mathrm{pH}$ of 6-7.

Therefore, future investigations regarding the tyrosinase from these multi-enzyme producing species should be directed at genetic manipulations and directed evolution, which would palliate the industrial production of tyrosinase from these species. 


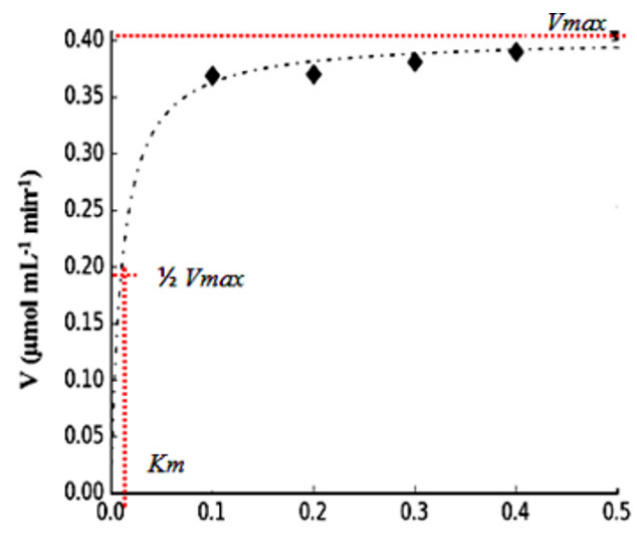

(a)
$[\mathrm{S}](\mathrm{mM})$

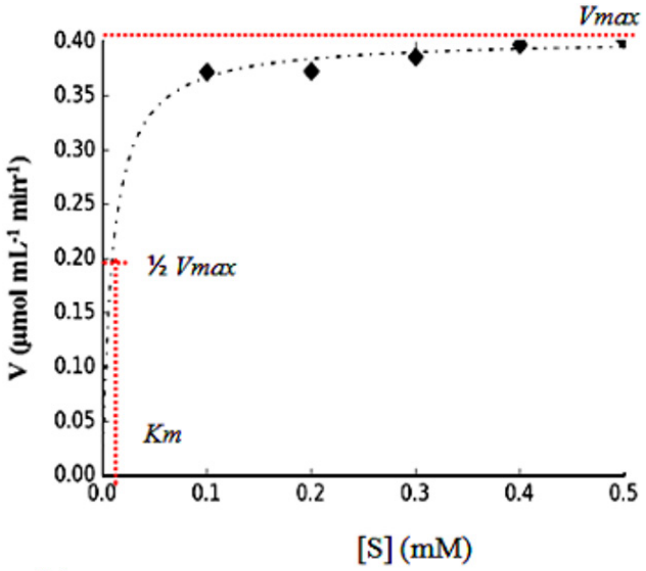

(b)

Fig. 9 Michaelis-Menten plot of the enzymatic activity of (a) Fusarium solani B1 and (b) Fumago sp. B13 tyrosinase at increasing substrate concentrations.

\section{References}

[1] Liu, J., Sidhu, S. S., Wang, M. L., Tonnis, B., Habteselassie, M., Mao, J., Huang, Q. "Evaluation of various fungal pretreatment of switchgrass for enhanced saccharification and enzyme production", Journal of Cleaner Production, 104, pp. 480-488, 2015. https://doi.org/10.1016/j.jclepro.2015.04.094

[2] Kang, S-Y., Heo, K. G., Hong, Y-S. "Optimization of artificial curcumin biosynthesis in E.coli by randomized 5'-UTR sequences to control the multienzyme pathway", ACS Synthetic Biology, 7(9), pp. 2054-2062, 2018. https://doi.org/10.1021/acssynbio.8b00198

[3] Qadir, F., Shariq, M., Ahmed, A., Sohail, M. "Evaluation of a yeast co-culture for cellulase and xylanase production under solid state fermentation of sugarcane bagasse using multivariate approach", Industrial Crops and Products, 123, pp. 407-415, 2018.

https://doi.org/10.1016/j.indcrop.2018.07.021

[4] France, S. P., Hepworth, L. J., Turner, N. J., Flitsch, S. L. "Constructing biocatalytic cascades: in vitro and in vivo approaches to de Novo multi-enzyme pathways", ACS Catalysis, 7(1), pp. 710-724, 2017.

https://doi.org/10.1021/acscatal.6b02979

[5] Shepherd, L. V. T., Alexander, C. J., Hackett, C. A., McRae, D., Sungurtas, J. A., Verrall, S. R., Morris, J. A., Hedley, P. E., Rockold, D., Belknap, W., Davies, H. V. "Impacts on the metabolome of down-regulating polyphenol oxidase in potato tubers", Transgenic Research, 24(3), pp. 447-461, 2015.

https://doi.org/10.1007/s11248-014-9850-8

[6] Hamann, J. N., Herzigkeit, B., Jurgeleit, R., Tuczek, F. "Smallmolecule models of tyrosinase: from ligand hydroxylation to catalytic monooxygenation of external substrates", Coordination Chemistry Reviews, 334, pp. 54-66, 2017. https://doi.org/10.1016/j.ccr.2016.07.009

[7] Cordero, R. J. B., Casadevall, A. "Functions of fungal melanin beyond virulence", Fungal Biology Reviews, 31(2), pp. 99-112, 2017. https://doi.org/10.1016/j.fbr.2016.12.003
[8] Xu, D.-Y., Chen, J.-Y., Yang, Z. "Use of cross-linked tyrosinase aggregates as catalyst for synthesis of L-DOPA", Biochemical Engineering Journal, 63, pp. 88-94, 2012. https://doi.org/10.1016/j.bej.2011.11.009

[9] Zaidi, K. U., Ali, A. S., Ali, S. A., Naaz, I. "Microbial tyrosinases: promising enzymes for pharmaceutical, food bioprocessing, and environmental industry", Biochemistry Research International, ID 854687,2014

https://doi.org/10.1155/2014/854687

[10] Fang, Y., Ramasamy, R. P. "Detection of p-ethylphenol, a major plant volatile organic compound, by tyrosinase-based electrochemical biosensor", ECS Journal Solid State Science and Technology, 5(8), pp. M3054-M3059, 2016. https://doi.org/10.1149/2.0101608jss

[11] Harir, M., Bellahcene, M., Baratto, M. C., Pollini, S., Rossolini, G. M., Trabalzini, L., Fatarella, E., Pogni, R. "Isolation and characterization of a novel tyrosinase produced by sahara soil actinobacteria and immobilization on nylon nanofiber membranes", Journal of Biotechnology, 265, pp. 54-64, 2018. https://doi.org/10.1016/j.jbiotec.2017.11.004

[12] Islam, F., Roy, N. "Screening, purification and characterization of cellulase from cellulase producing bacteria in molasses", BMC Research Notes, 11, pp. 445, 2018. https://doi.org/10.1186/s13104-018-3558-4

[13] Pinto, G. A. S., Leite, S. G. F., Terzi, S. C.,Couri, S. "Selection of tannase-producing Aspergillus niger strains", Brazilian Journal of Microbiology, 32(1), pp. 24-26, 2001. https://doi.org/10.1590/S1517-83822001000100006

[14] Polley, T., Ghosh., U. "Isolation and identification of potent alkaline protease producing microorganism and optimization of biosynthesis of the enzyme using RSM", Indian Chemical Engineer, 60(3), pp. 285-296, 2018. https://doi.org/10.1080/00194506.2017.1376600 
[15] Raval, K. M., Vaswani, P. S., Majumder, D. R. "Biotransformation of a single amino acid $\mathrm{L}$ tyrosine into a bioactive molecule LDOPA", International Journal of Scientific Research, 2(5), pp. 1-9, 2012. Available at: https://pdfs.semanticscholar.org/3elf/ e8f7859335a9db863f832232cf8e8afb8630.pdf [Accessed: 25 November 2018]

[16] Benson, H. J. "Microbiological Applications Lab Manual", 8th ed., McGraw Hill Education Publishing Company, New York, USA, 2001.

[17] Wanatabe, T. "Identification of Fungi", In: Pictorial Atlas of Soil and Seed Fungi, Morphologies of Cultured Fungi and Key to Species. 3rd ed., CRC Press., Boca Raton, USA, pp. 9-11, 2010. https://doi.org/10.1201/EBK1439804193

[18] Roy, S., Das, I., Munjal, M., Karthik, L., Kumar, G., Kumar, S., Rao, K. V. B. "Isolation and characterization of tyrosinase produced by marine Actinobacteria and its application in the removal of phenol from aqueous environment", Frontiers in Biology, 9(4), pp. 306-316, 2014.

https://doi.org/10.1007/s11515-014-1324-0

[19] Naraoka, T., Uchisawa, H., Mori, H., Matsue, H., Chiba, S., Kimura, A. "Purification, characterization and molecular cloning of tyrosinase from the cephalopod mollusc, Illex argentines", European Journal of Biochemistry banner, 270(19), pp. 4026-4038, 2003. https://doi.org/10.1046/j.1432-1033.2003.03795.x

[20] Bradford, M. M. "A rapid and sensitive method for the quantitation of microgram quantities of protein utilizing the principle of protein dye binding", Analytical Biochemistry, 72(1-2), pp. $248-254,1976$. https://doi.org/10.1016/0003-2697(76)90527-3

[21] Balakrishnan, G. S., Kalirajan, J. . "Identification of tyrosinase from Dioscorea alata tuber extract by homology driven proteomics approach", Current Proteomics, 13(1), pp. 1-8, 2016. https://doi.org/10.2174/1570164613666160407120320

[22] Halaouli, S., Asther, M., Sigoillot, J.-C., Hamdi, M., Lomascolo, A. "Fungal tyrosinases: New prospects in molecular characteristics, bioengineering and biotechnological applications", Journal of Applied Microbiology, 100(2), pp. 219-232, 2006. https://doi.org/10.1111/j.1365-2672.2006.02866.x

[23] Valipour, E.,Arikan, B. "Increased production of tyrosinase from Bacillus megaterium strain M36 by the response surface method", Archives of Biological Science, 68(3), pp. 659-668, 2016. https://doi.org/10.2298/ABS151002058V

[24] Krishnaveni, R., Rathod, V., Thakur, M. S., Neelgund, Y. F. "Transformation of 1-tyrosine to 1-dopa by a novel fungus, Acremonium rutilum, under submerged fermentation", Current Microbiology, 58(2), pp. 122-128, 2009. https://doi.org/10.1007/s00284-008-9287-5

[25] Agarwal, P., Dubey, S., Singh, M., Singh, R.P. "Aspergillus niger PA2 tyrosinase covalently immobilized on a novel eco-friendly bio-composite of chitosan-gelatin and its evaluation for L-DOPA production", Frontiers in Microbiology, 7, pp. 2088, 2016. https://doi.org/10.3389/fmicb.2016.02088
[26] Moshtaghioun, S. M., Dadkhah, M., Bahremandjo, K., Haghbeen, K., Aminzadeh, S., Legge, R. L. "Optimization of simultaneous production of tyrosinase and laccase by Neurospora crassa", Biocatalysis and Biotransformation, 35(1), pp. 1-10, 2017. https://doi.org/10.1080/10242422.2016.1266617

[27] Faccio, G., Kruus, K., Saloheimo, Thöny-Meyer, L., "Bacterial tyrosinases and their applications", Process Biochemistry, 47(12), pp. 1749-1760, 2012. https://doi.org/10.1016/j.procbio.2012.08.018

[28] Majidi, D., Aksöz, N. "Stability of tyrosinase enzyme from Funalia Trogii", American Journal of Microbiological Research, 1(1), pp. 1-3, 2013.

https://doi.org/10.12691/ajmr-1-1-1

[29] Duarte, L. T., Tiba, J. B., Santiago, M. F., Garcia, T. A., Bara, M. T. F. "Production andcharacterization of tyrosinase activity in Pycnoporus sanguineus CCT-4518 crude extract", Brazilian Journal of Microbiology, 43(1), pp. 21-29, 2012. https://doi.org/10.1590/S1517-83822012000100003

[30] Bayranoglu, G., Akbulut, A., Arica, M. Y. "Immobilization of tyrosinase on modified diatom biosilica: enzymatic removal of phenolic compounds from aqueous solution", Journal of Hazardous Materials, 244-245, pp. 528-536, 2013. https://doi.org/10.1016/j.jhazmat.2012.10.041

[31] Axambayeva, A. S., Zhaparova, L. R., Shagyrova, Zh, S., Ramankulov, E. M., Shustov, A. V. "Unusual stability of a recombinant Verrucomicrobium spinosum tyrosinase to denaturing agents and its use for a production of a protein with adhesive properties", Applied Biochemistry and Biotechnology, 185(3), pp. 736-754, 2018. https://doi.org/10.1007/s12010-017-2686-y

[32] Zou, Y., Hu, W., Jiang, A., Ma, K. "Partial purification and characterization of a novel extracellular tyrosinase from Auricularis auricula", Applied Biochemistry and Biotechnology, 172(3), pp. 1460-1469, 2014. https://oi.org/10.1007/s12010-013-0638-8

[33] Marasović, M., Marasović, T., Milos, M. "Robust nonlinear regression in enzyme kinetics parameters estimation", Journal of Chemistry, 2017, ID: 6560983, 2017. https://doi.org/10.1155/2017/6560983

[34] Pretzler, M., Bijelic, A., Rompel, A. "Heterologous expression and characterization of functional mushroom tyrosinase (A $b$ PPO4)", Scientific Reports, 7(1), pp. 1810, 2017. https://oi.org/10.1038/s41598-017-01813-1

[35] Wan, X., Chai, B., Liao,Y., Su, Y., Ye, T., Shen, P., Chen, X. "Molecular and biochemical characterization of a distinct tyrosinase involved in melanon production from Aeromonas media", Applied Microbiology and Biotechnology, 82, pp. 261-269, 2008. https://doi.org/10.1007/s00253-008-1742-5

[36] Selinheimo, E., Saloheimo, M., Ahola, E., Westerholm-Parvinen, A., Kalkkinen, N., Buchert, J., Kruus, K. "Production and characterization of a secreted, C-terminally processed tyrosinase from the filamentous fungus Trichoderma reesei", The FEBS Journal, 273(18), pp. 4322-4335, 2006. https://doi.org/10.1111/j.1742-4658.2006.05429.x 